\title{
A Systematic Review of Sustainable Banking through a Co-Word Analysis
}

\author{
Juan J. Nájera-Sánchez \\ Facultad de Ciencias Jurídicas y Sociales, Universidad Rey Juan Carlos, Paseo de los Artilleros, 28032 Madrid, \\ Spain; juanjose.najera@urjc.es
}

Received: 26 November 2019; Accepted: 27 December 2019; Published: 30 December 2019

\begin{abstract}
The 2008 financial crisis placed banks in the gaze of public opinion. Financial entities did not delay in reacting, intensifying their efforts in what had become known as sustainable banking, with the goal of counteracting the negative effects of their loss of reputation. Neither has the academic community delayed their reaction, with the rapid growth of scientific production around this topic. However, no review of this literature through qualitative methods or bibliometry exists. The work presented in this paper fills one of those gaps, setting up a statistical description of the principal features of sustainable banking research and carrying out an analysis about its knowledge structure via co-word analysis. The results show a rapid evolution of the topics addressed, highlighting studies about the consequences of banks' sustainability programs on their competitiveness. Future trends point to the search for more complex models, the incorporation of new stakeholders in the analysis and the consideration of different contexts.
\end{abstract}

Keywords: sustainable banking; corporate social responsibility; ethical banking; bibliometrics; co-word analysis

\section{Introduction}

There is a vast quantity of literature regarding the enormous influence of the banking sector on the economy [1,2]. Its fundamental role in the channeling of funds, from savings to investment, gives it decisive influence over which activities do or do not receive financing. As such, it has a unique intermediary role in sustainable development [3-5].

In today's world, sustainability is a constant in the way business is done. Organizations like the United Nations, World Business Council for Sustainable Development and Global Reporting Initiative have developed principles of, and criteria for sustainability. Sustainability is the new language of business, requiring that firms not only maintain financial strength (for shareholders), but also manage their social environmental impacts on the broader stakeholder community [6].

Banks, far from avoiding this trend, have shown significant proactivity, motivated for various reasons, among which, the one mentioned most often has to do with the 2008 financial crisis. First, for the role banks played in the crisis, contributing in a definitive manner with their poor ethical behavior [7]. Second, for the consequences resulting from the crisis (loss of confidence), which lead entities to look for strategies based in corporate social responsibility (CSR) as a means to recover their reputation with different stakeholders [8-10].

These factors have resulted in vigorous growth in this line of research about sustainable banking in recent years. However, there are no reviews of the literature, whether following more traditional procedures or a bibliometric approach, that have tried to establish what is the social, intellectual or knowledge structure of the subject. Such knowledge is of vital importance, as much for the researchers currently engaged with the subject as for those intending to become part of the research effort. This is precisely the contribution this paper is trying to make. 
Sustainable banking is a terminological jungle, which includes many topics. Bouma, Jeucken and Klinkers [11] highlight several topics that the term "sustainable banking" comprises: the environmental policies of banks, the importance of transparency and communication between banks and their stakeholders, and the key role of government, NGOs and multilateral banks in delivering sustainability, among others. In fact, the sustainability concept has been divided into three central factors or axes: environmental, social and governance. These three factors have not always been dealt with at the same time, nor have they always been referred to with the same words. In fact, a relevant part of the literature in this topic has used the term CSR to talk about sustainability, in banks or in other industries. All these topics, in the specific context of the banking industry, are the focus of this research.

This paper has a double objective. On one hand, it takes a descriptive approach to the subject literature, characterizing the scientific production in sustainable banking as it has evolved over time, including authorship, collaboration, affiliation and main publications. On the other hand, a co-word analysis was developed, with the goal of determining the knowledge structure of this research topic.

The study derives three principal conclusions from its two objectives. First, the subject has awakened growing interest, especially beginning with the 2008 financial crisis, with an unprecedented acceleration in the last two years. The relevance of sustainable banking in the real world, has been translated to the academic world. Furthermore, the availability of data and ever greater measurement of activities linked to CSR make the research more viable. Second, there has been an important thematic evolution: while the studies from the years immediately following the crisis concentrate more on directly related aspects, current studies focus on the effects of sustainability actions on different stakeholders, with special attention to clients, in the degree to which these actions have served to influence banks' reputations, as a competitive weapon. Finally, future trends point to greater interest in other stakeholders and the study of new contexts, with special attention to developing countries.

The organization of the article begins with the descriptive study, establishing the criteria used to obtain the sample of studies included in the analysis with precision, and carrying out the descriptive bibliometric study. The third section has a succinct description of the co-word analysis and presents the results of the two periods included-2009-2014 and 2015-2019-analyzing the subject's evolution. The conclusion summarizes the most highlighted aspects of the study and establishes some trends and future lines of research.

\section{Data and Descriptive Analysis}

The information to carry out this analysis has been gathered from the Web of Science (WoS) database, the most prestigious and widely used database in fields related to social sciences to make bibliometric studies [12]. The first step in the analysis is gathering the data. Different terms have been used to refer to the phenomena of sustainable banking over time. This makes it more difficult to design a search protocol that will retrieve all the relevant documents related to the topic. The final search protocol appears in Table 1.

Table 1. Search protocol.

\begin{tabular}{|c|c|c|c|}
\hline $\begin{array}{c}\text { Document } \\
\text { Type }\end{array}$ & Database & Fields & Keywords \\
\hline $\begin{array}{l}\text { Article } \\
\text { Review }\end{array}$ & $\begin{array}{l}\text { Social Science } \\
\text { Citation Index }\end{array}$ & $\begin{array}{c}\text { Title } \\
\text { Keywords } \\
\text { Abstract }\end{array}$ & $\begin{array}{l}\text { (sustainab * OR "social * responsib *" OR } \\
\text { "corporate social" OR "efficien * social" OR } \\
\text { "social efficien *" OR "social performance" } \\
\text { OR “environment *" OR CSR OR SDG or } \\
\text { ESG or ethic *) NEAR/10 (bank * OR } \\
\text { "financ* industry" OR "financ * sector") }\end{array}$ \\
\hline
\end{tabular}

The search protocol takes two groups of terms into account. First, it tries to gather all the possible ways to refer to "sustainable". This topic has been studied by different disciplines and in different moments with different names, such as corporate social responsibility (CSR), social responsibility and 
ethical banking, among others. Several papers that refer to the environmental responsibility of banks must also be included in the analysis. Others have written about socially efficient banking. Finally, terms like SDG (Sustainable Development Goals) and ESG (environmental, social and governance) have become common in this topic. As a result, the first part of the query includes all of these terms. The second part contains different terms to refer to the banking of the financial industry.

To try to avoid a very high number of false positives, the query retrieves only the documents in which at least one of the terms of each group appear, and the distance between them is less than 10 words (NEAR operator). The search was conducted in December 2019. No restrictions in time scope were set. The Social Science Citation Index section was selected because the topic is focused in this area. To exclusively consider tested knowledge, the search was restricted to two kinds of documents: articles and reviews. The query was directed to the Title, Keywords and Abstract fields. The search retrieved 1617 documents.

All of the Titles and Keywords were reviewed to ensure they matched the topic. In some cases, it was necessary to read the abstract to confirm whether or not the articles dealt with the topic. This additional step in the review process lead to the realization that many of the documents retrieved were false positives. As a consequence of this review and filtering process, a large amount of documents was removed from the sample. The most common false positives were: studies about other kinds of banks (not financial); documents using the term "sustainable performance" to study only financial sustainability; the term "environment" used with a different meaning and numerous works that use "World Bank" database, but do not study anything about the banking industry. After the filtering process, only 255 documents remained in the sample. Figure 1 shows the distribution of these documents over time.

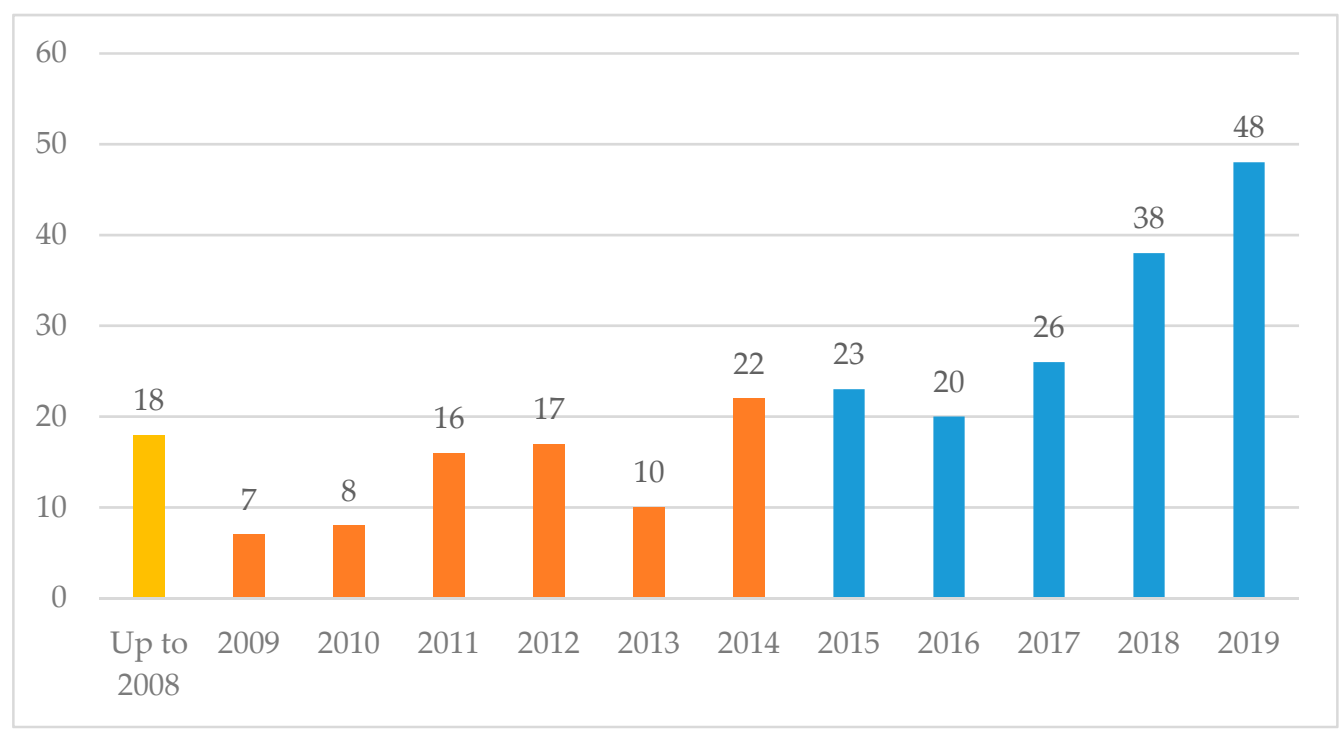

Figure 1. Evolution of sustainable banking research documents.

Before 2008 the number of research documents about the subject was scarce and scattered across various fields. As several authors have highlighted, research has excluded the financial sector, and especially CSR, for different reasons. Only after the 2008 financial crisis has this research topic become important. After the crisis, financial entities lost the trust of their customers. To recover their competitive ability, bans looked for ways to build a new relationship with clients and found that CSR actions could be a solid base from which to grow confidence $[13,14]$. As banks were beginning or improving their programs related to corporate social, environmental and governance actions, academics did not hesitate to start analyzing those actions.

In Figure 1 we can distinguish three periods of time: first, prior to and including 2008; second, 2009-2014; and finally, 2015-2019. The division of the last two periods is based on the fact that one of 
our research aims is the study of the main subtopics and their evolution. In bibliometric literature it is common to find five year periods to analyze progress over time $[15,16]$.

A little more than $7 \%$ of the documents were published before 2009 . Over $30 \%$ of the articles and reviews were issued in the second period, with remarkable growth in 2011 and 2014. Finally, more than $60 \%$ of the research works were published in the third period. The last two years have been especially productive.

In the next section, I analyzed different aspects related to the authors and sources of this research. Next I analyzed the most influential works in our database. Finally, I made a co-word analysis to study the different subtopics that have been dealt with in our sample, analyzing their evolution and focusing in the third period to establish possible future subtopics in this line of research.

\subsection{Authors}

The figures show that in this topic the number of co-authors ranges from one to three in $86.17 \%$ of all cases. It is remarkable that $84.58 \%$ of the documents had two or more co-authors, with the maximum being six (Table 2). These data suggest several facts about the academic community engaged with this topic. First, it is a very young topic and interest in it emerged after the main topic was well-developed. In fact, this topic is the result of a fusion of two main topics: CSR and the banking industry. Both topics have been developed separately for years, but the intensive study of both together is recent. When a topic begins to be studied, collaboration among academics is a frequent behavior because of its advantages in terms of quality $[17,18]$ and research impact $[19,20]$, as a result of the complementarity among researchers. However, evaluation processes for research activity place a negative value on social sciences papers with more than three co-authors [21]. In fact, journals increasingly ask for additional information to justify why a paper has a higher number of authors.

Table 2. Co-authors per document.

\begin{tabular}{cccc}
\hline Co-Authors Per Document & Frequency & Percentage (\%) & Cumulated Percentage (\%) \\
\hline 1 & 39 & 15.42 & 15.42 \\
2 & 96 & 37.94 & 53.36 \\
3 & 83 & 32.81 & 86.17 \\
4 & 24 & 9.49 & 95.65 \\
5 & 9 & 3.56 & 99.21 \\
6 & 2 & 0.79 & 100.00 \\
\hline
\end{tabular}

Table 3 shows the number of documents per author in this topic. To do this calculation, I have considered the number of participations of the authors, without taking into account the number of co-authors in each document.

Table 3. Document per author.

\begin{tabular}{cc}
\hline Documents Per Author & Frequency \\
\hline 1 & 458 \\
2 & 51 \\
3 & 11 \\
4 & 3 \\
5 & 1 \\
6 or more & 2 \\
\hline
\end{tabular}

In our sample, there are 526 different authors who have co-authored at least one document. Around $85 \%$ of these authors have published just one research work in our database. More than $9.5 \%$ have authored two, and around $2 \%$ have signed three. This distribution confirms the youth of the topic.

Lotka's Law [22,23], one of the laws of bibliometry, establishes that the distribution of authors according to their productivity conforms to a pattern: the number of researchers who have authored 
" $n$ " works on a topic is inversely proportional to the square of " $\mathrm{n}$ ". In other words, the law states that a relatively small number of authors tend to produce most of the works in a particular area. Figure 2 shows the Lotka distribution for the articles related to the field analyzed. We can see that the evolution moderately aligned with the distribution proposed by this bibliometric law. This fact can demonstrate an initial evolution of this research topic.

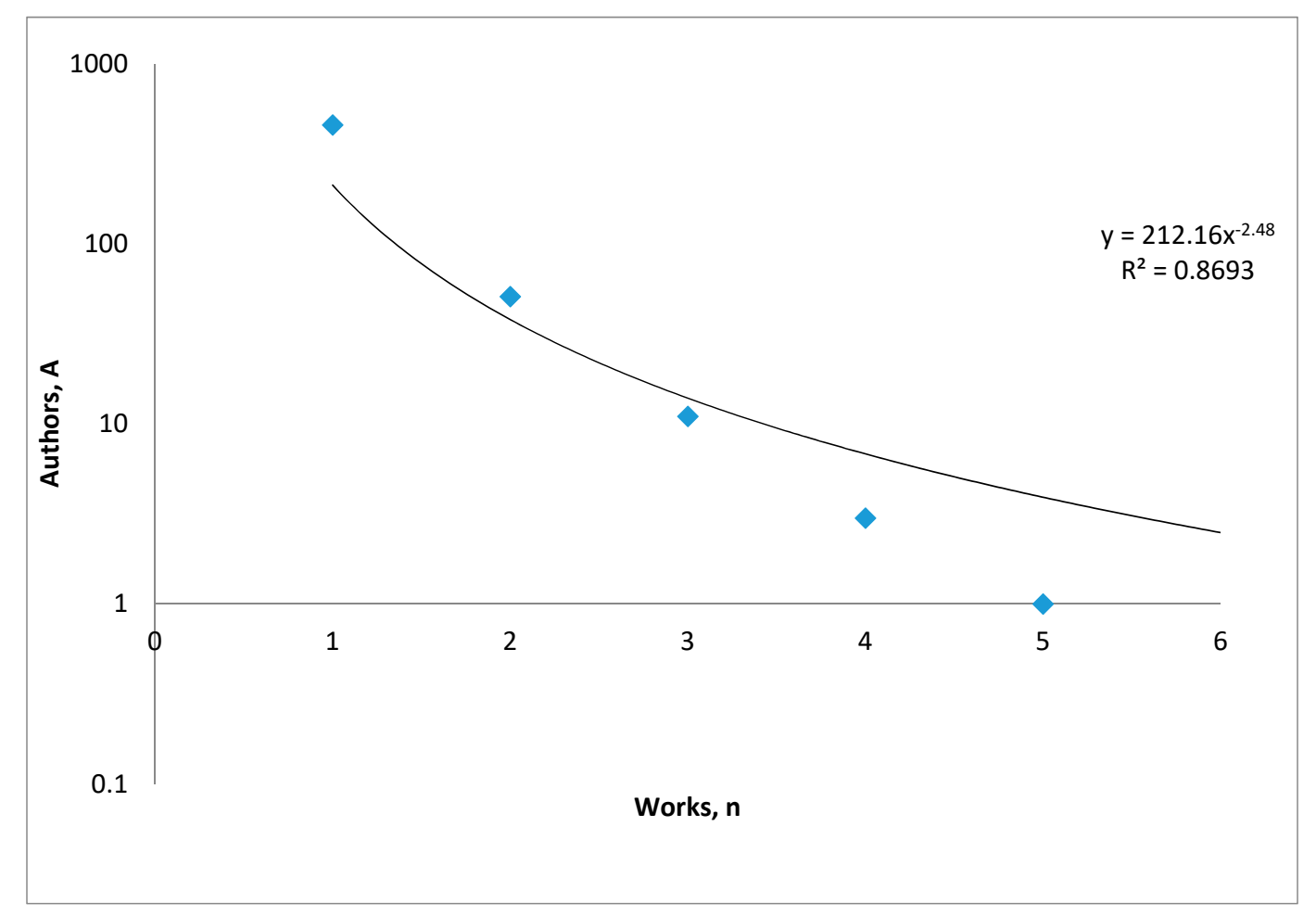

Figure 2. Lotka's Law in the sustainable banking topic.

Table 4 contains the most productive authors in the topic and some data about their research activity. It is a very heterogeneous group. Two professors at the Universidad de Cantabria, Andrea Pérez and Ignacio Rodríguez del Bosque, are the most productive researchers in this topic. They have published numerous documents in the last few years. Their impact is high potential, especially that of professor Pérez (consulted in Google Scholar) due to the youth of her career. Professor Bert Scholtens stands out as a reference in this topic, especially because of his work in 2009. Finally, the figures of professors Aracil and Seguí-Pérez are remarkable. Their metrics in Google Scholar denote careers in their first stages, but they have published several papers on this topic. Additionally, we note both of them have a large ratio between number of documents and number of participations. In other words, they have not published papers with a lot of co-authors. 
Table 4. Most productive authors in sustainable banking topic.

\begin{tabular}{ccccc}
\hline & & & \multicolumn{2}{c}{ Google Scholar Metrics } \\
\hline Author & \# Documents & \# Participations & Citations & H Index \\
\hline Perez A & 6.00 & 13 & 2052 & 22 \\
\hline Rodriguez-del Bosque, I & 4.83 & 10 & n.a. & n.a. \\
\hline Scholtens B & 2.45 & 5 & 7332 & 42 \\
\hline Aracil E & 2.33 & 4 & 64 & 3 \\
\hline Ferreira FAF & 1.37 & 4 & 1250 & 21 \\
\hline Martinez-Campillo A & 1.50 & 4 & 573 & 10 \\
\hline Matute-Vallejo J & 1.00 & 3 & 1596 & 18 \\
\hline Segui-Alcaraz A & 2.50 & 3 & 42 & 4 \\
\hline Weber O & 2.33 & 3 & 6006 & 1739 \\
\hline Rahman Z & 1.17 & 3 & 2263 & 21 \\
\hline Pina JM & 1.00 & 3 & n.a. & n.a. \\
\hline Garcia-De los Salmones MD & 0.83 & 3 & n.a. & n.a. \\
\hline Bravo R & 0.92 & 3 & 3072 & 24 \\
\hline Garcia-Meca E & 1.33 & 3 & 535 & 15 \\
\hline Jalali MS & 0.87 & 3 & 4858 & 16 \\
\hline Forcadell FJ & 1.33 & 3 & 11 \\
\hline Fatma M & 1.17 & 356 & & \\
\hline
\end{tabular}

To complete the study about the authors, I studied their affiliations. Table 5 summarizes the top 10 countries in research production for this topic. Table 6 shows the scientific production grouped by continent. In Table 7 the most productive universities are shown

Table 5. Most productive countries in sustainable banking topic.

\begin{tabular}{ccccc}
\hline Title & Up to 2008 & 2009-2014 & 2015-2019 & Total \\
\hline Spain & 1.00 & 18.25 & 36.25 & 55.50 \\
England & 3.00 & 5.32 & 13.88 & 22.20 \\
USA & 2.00 & 6.64 & 10.45 & 19.09 \\
Italy & 1.00 & 3.00 & 11.28 & 15.28 \\
Peoples R China & & 3.00 & 7.45 & 10.45 \\
France & 3.00 & 1.64 & 5.62 & 10.26 \\
Netherlands & 2.00 & 4.50 & 3.27 & 9.77 \\
Germany & 1.00 & 1.00 & 7.15 & 9.15 \\
India & & 2.00 & 6.83 & 8.83 \\
Australia & 1.00 & 3.50 & 2.92 & 7.42 \\
\hline
\end{tabular}

Table 6. Scientific production in sustainable banking topic by continent.

\begin{tabular}{ccccc}
\hline Continent & Up to 2008 & 2009-2014 & 2015-2019 & Documents \\
\hline Africa & 0.00 & 1.00 & 1.50 & 2.50 \\
Asia & 0.00 & 13.33 & 28.05 & 41.38 \\
Europe & 11.00 & 46.55 & 100.08 & 157.63 \\
North-America & 2.00 & 10.62 & 12.95 & 25.57 \\
Oceania & 1.00 & 3.50 & 2.92 & 7.42 \\
South-America & 0.00 & 1.00 & 3.50 & 4.50 \\
\hline
\end{tabular}


Table 7. Most productive universities in sustainable banking topic.

\begin{tabular}{ccccc}
\hline University/Institutions & Up to 2008 & 2009-2014 & 2015-2019 & Total \\
\hline Univ Cantabria & & 3.00 & 9.50 & 12.50 \\
Univ Zaragoza & & 3.00 & 1.67 & 4.67 \\
Univ Groningen & \multirow{2}{*}{00} & 2.50 & 0.90 & 4.40 \\
Univ Extremadura & & & 4.00 & 4.00 \\
Univ Jaume I Castellon & \multirow{2}{*}{1.00} & 1.00 & 1.83 & 3.83 \\
Univ Leon & & 2.00 & 1.33 & 3.33 \\
Univ Valencia & & 1.50 & 1.50 & 3.00 \\
Bucharest Univ Econ Studies & & 1.50 & 1.00 & 2.50 \\
Univ Waterloo & 1.50 & 1.00 & 2.50 \\
Univ Oviedo & 1.00 & 1.50 & 2.50 \\
Univ Castilla La Mancha & & 1.00 & 1.50 & 2.50 \\
Univ Pontificia Comillas & & 2.17 & 2.17 \\
\hline
\end{tabular}

It is remarkable that Spain ranks first as the most productive country in this topic, with a significant gap between first and second (England). This situation begins in 2009 and continues to the present. Six out of ten countries on the list are from Europe. This is coherent with Table 6, in which it is possible to see that Europe has produced more documents about this topic than the rest of the world combined. I have to highlight the low productivity of the United States in this topic because although it appears in the top five, this is not the usual situation in bibliometrics in the business and management field. Finally, the behavior of China and India as the most productive countries in Asia shows the evolution of this topic in these countries. We can see that it is especially prolific in the third period.

In Table 7 we found all the universities whose professors have published more than two documents (using the fractional counting method). It is noteworthy that 8 out of 11 institutions are from Spain. The University of Cantabria stands out as an extraordinary case.

\subsection{Journals}

It is interesting to study which journals have published literature about sustainable banking. There are 111 different publications in the sample. Table 8 shows the six journals that have published the most, with number of documents and overall percentage. We can see that the Journal of Business Ethics published more than $18 \%$ of the research works, which form our database, and that Sustainability, despite its newness in WoS, has also accumulated a relevant percentage. However, the most noticeable piece of data is the breadth (atomization/spray) of the research: of the 111 journals, 79 (more than $70 \%$ ) have only published one document related to this topic, while 15 have published works on two occasions (more than 13\%).

Table 8. Most frequent journals in sustainable banking topic.

\begin{tabular}{ccc}
\hline Journal & \# Documents & Percentage (\%) \\
\hline Journal of Business Ethics & 45 & 17.79 \\
Sustainability & 21 & 8.30 \\
Corporate Social Responsibility and Environmental Management & 16 & 6.32 \\
International Journal of Bank Marketing & 11 & 4.35 \\
Journal of Cleaner Production & 7 & 2.77 \\
Business Strategy and The Environment & 5 & 1.98 \\
\hline
\end{tabular}

Together with this fact, the very diverse nature of these publications is also noteworthy. To observe this topic more clearly, the WoS categories to which the journals belong have been analyzed, taking into account that a multidisciplinary journal may appear in more than one category. Table 9 summarizes these categories and their frequency. 
Table 9. Most frequent categories of Web of Science (WoS) in the sustainable banking topic.

\begin{tabular}{ccc}
\hline WoS Category & Frequency & Percentage \\
\hline Business & 128 & 50.59 \\
Management & 59 & 23.32 \\
Environmental Studies & 54 & 21.34 \\
Ethics & 52 & 20.55 \\
Economics & 41 & 16.21 \\
Green and Sustainable Science and Technology & 36 & 14.23 \\
Environmental Sciences & 35 & 13.83 \\
Business, Finance & 23 & 9.09 \\
\hline
\end{tabular}

In total, the 253 documents analyzed were published in journals appearing in 38 different WoS categories. We can observe that the principal category, as expected, is Business, with more than $50 \%$ of the publications appearing in this category. At high frequency, but at a clear distance, we found four more categories: Management, Environmental Studies, Ethics and Economics. Other relevant categories are related to environmental issues.

\section{Subtopics in Sustainable Banking: A Co-Word Analysis Approach}

We used the co-word analysis method to identify relationships between topics in a research field, thus observing how the science develops [24]. The method is also applied using a longitudinal approach to trace the research field's evolution across consecutive periods of time [25]. A general co-word analysis has two targets. First, the detection of hierarchies among areas of a research problem. Second, the identification of minor but potentially growing areas [24].

Callon et al. [26] first proposed the co-word analysis method as a relevant means of identifying and representing links between concepts from textual information. In this content analysis technique, models of the co-occurrence of pairs of items in a set of articles or texts are used to detect relationships between ideas within knowledge areas [24]. Thus it is understood that the items are representative of their texts. Accordingly, they hold the key ideas contained in the texts. So, the appearance of these links between concepts involves the presence of relationships between topics, represented by items [24].

The co-word analysis method has been used to identify themes within a particular area of research, relationships between these themes, their degree of centrality to a broader area and the extent to which they are internally structured [24]. It is the only approach to construct a similarity measure using the actual content of documents. In contrast, other methods identify indirect relationships between documents based on citations or co-authorships [12].

Zupic and Čater [12] explain that a co-word analysis produces a network of themes and the relationships between them (a semantic map), which represents the conceptual space of a field-cognitive structure. Furthermore, semantic maps from different time periods can show changes in this conceptual space [27].

To identify and illustrate major conceptual subdomains developed, and pinpoint principal themes in the field analyzed, this paper presents a co-word analysis based on the approach proposed by Cobo et al. [15], who describe a form of analysis carried out in four stages. Stage one is theme identification. In this stage, main themes of the research in the field analyzed (sustainable banking, ethical banking or corporate social responsibility in the financial sector) are identified. The existence of thematic networks can also be noted in this stage. Stage two is theme and thematic network visualization. In this stage, the themes and thematic networks distinguished in the previous stage are represented graphically. Stage three is theme evolution. Here an analysis of the themes' evolution is conducted. Finally, stage four is performance analysis. In this stage, different quantitative (number of documents, authors, journals and countries), qualitative or impact (citations received and bibliometric indices) measures are calculated. 


\subsection{First Stage}

In line with Cobo et al. [15], a five step process of theme detection was used: (1) raw data collection (Social Science Citation Index of WoS), (2) selection of item type for analysis (author keywords), (3) relevant information extraction from the raw data (co-occurrence frequencies of keywords), (4) calculation of item similarities based on the extracted information and (5) theme detection using a clustering algorithm.

An analysis of keywords related to the articles in the research sample was carried out to study the themes addressed in this line of research. In line with previous works, keywords were considered to be representative terms for the themes studied $[15,28]$. Further, the keywords analyzed were those used by the authors and the WoS database for each document. Prior to constructing the co-word analysis, the keywords were standardized in line with Choi et al. [28]. The following rules were used:

- Keywords were standardized into a unique form, e.g., ethic and ethics.

- Abbreviations were avoided. When both the original word and the abbreviated form(s) appeared in the keyword list, they were consolidated into the original word, e.g., corporate social responsibility, CSR.

- Synonyms were unified. When there were two or more synonyms in the list, they were exchanged for the most general keyword, e.g., traditional banking and conventional banking.

- Terms that were too general or did not have a clear meaning were eliminated, e.g., model, framework.

These rules were applied to 735 different keywords. This refinement produced a keyword database with 459 keywords. The most frequent keywords (WoS) appear in Table 10.

Table 10. Most frequent keywords in sustainable banking topic.

\begin{tabular}{cc}
\hline Keyword & Frequency \\
\hline corporate social responsibility & 127 \\
bank & 57 \\
banking sector & 38 \\
financial performance & 30 \\
CSR disclosure & 24 \\
financial crisis & 22 \\
corporate sustainability & 22 \\
loyalty & 18 \\
CSR performance & 16 \\
socially responsible investment (SRI) & 14 \\
CSR reporting & 14 \\
ethical banking & 14 \\
ethics & 12 \\
sustainable development & 11 \\
stakeholders & 10 \\
\hline
\end{tabular}

VOS Viewer software [29] was used to analyze the structure of the keyword network constructed from this database. In addition, Bibexcel [30] and Microsoft Excel were used to carry out a descriptive bibliometric analysis of the database. Finally Pajek [31] was used to perform a special analysis that could not be performed with VOS Viewer.

Principal research themes were pinpointed computing co-occurrences of keywords considered to be representative of each document based on the periods of time studied [32]. The decision was made to consider just two periods of time to perform the co-word analysis. The first period contains documents published from 2009 to 2014. The second period includes papers published from 2015 until November 2019.

The association index is calculated after calculating the co-occurrence matrix. There are various approaches in the literature to performing this calculation. One of the most common approaches is 
called association strength. This approach, following Van Eck and Walman [33], has advantages with respect to other measures. From the indexes that result from the calculation, a clustering algorithm is applied to identify subgroups of keywords that are strongly associated, and are topics on which researchers focus. Among techniques for applying clustering algorithms, the VOS algorithm stands out $[34,35]$. As a result of the application of the algorithm, it is possible to distinguish different thematic groups, which can then be characterized.

\subsection{Second Stage}

Co-words are used in mapping science to obtain clusters of keywords viewed as themes [15]. The second stage involves identifying themes and thematic networks. Figures 3 and 4 represent the co-word networks for the periods 2009-2014 and 2015-2019, respectively. To build them, I have considered just the terms that appear at least two times in the period 2009-2014, and three times in the period 2015-2019. In these networks I have used different colors to differentiate the thematic group associated with each term. To perform this analysis, four terms were removed because they are generic terms in the topic: "corporate social responsibility", "banks", "banking sector" and "sustainable banking". These terms have the potential to appear in every single document so it is not valuable to include them in the analysis. Additionally, terms that refer to research methods were omitted.

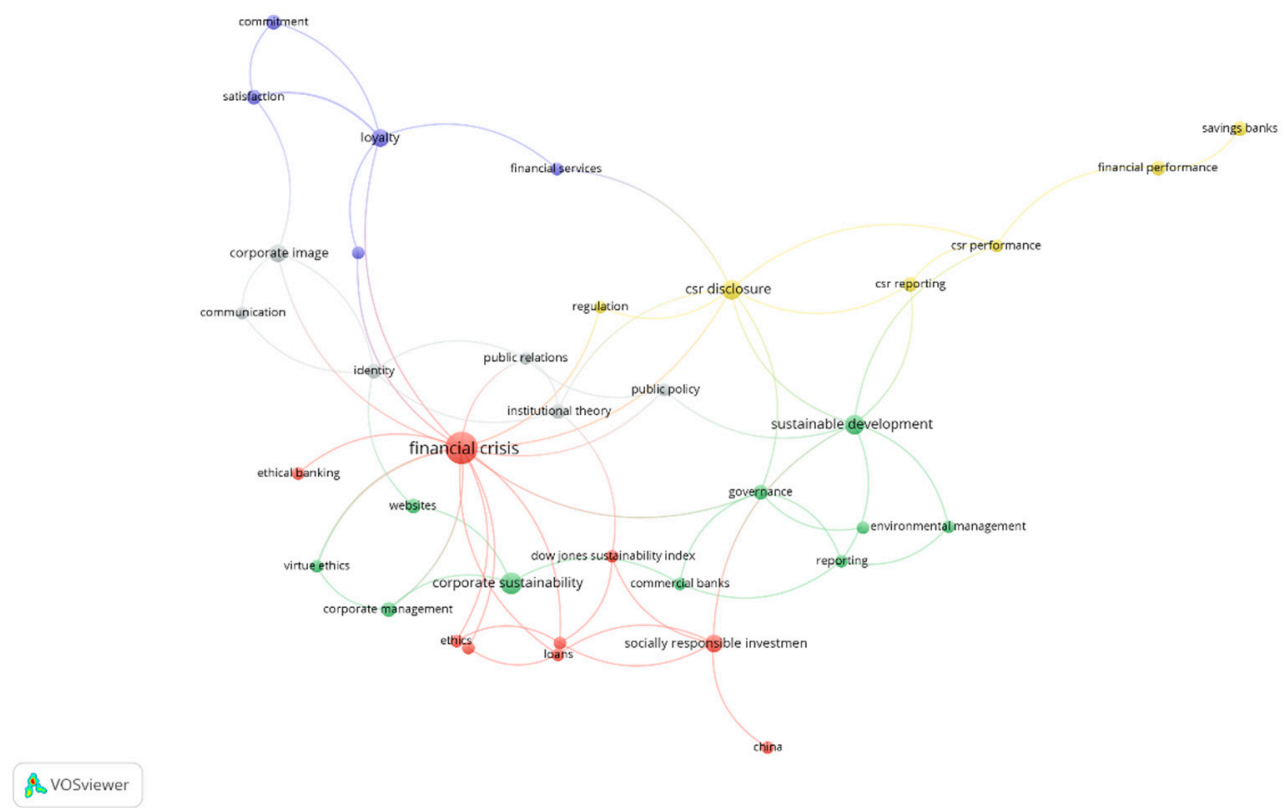

Figure 3. Thematic networks 2009-2014. 


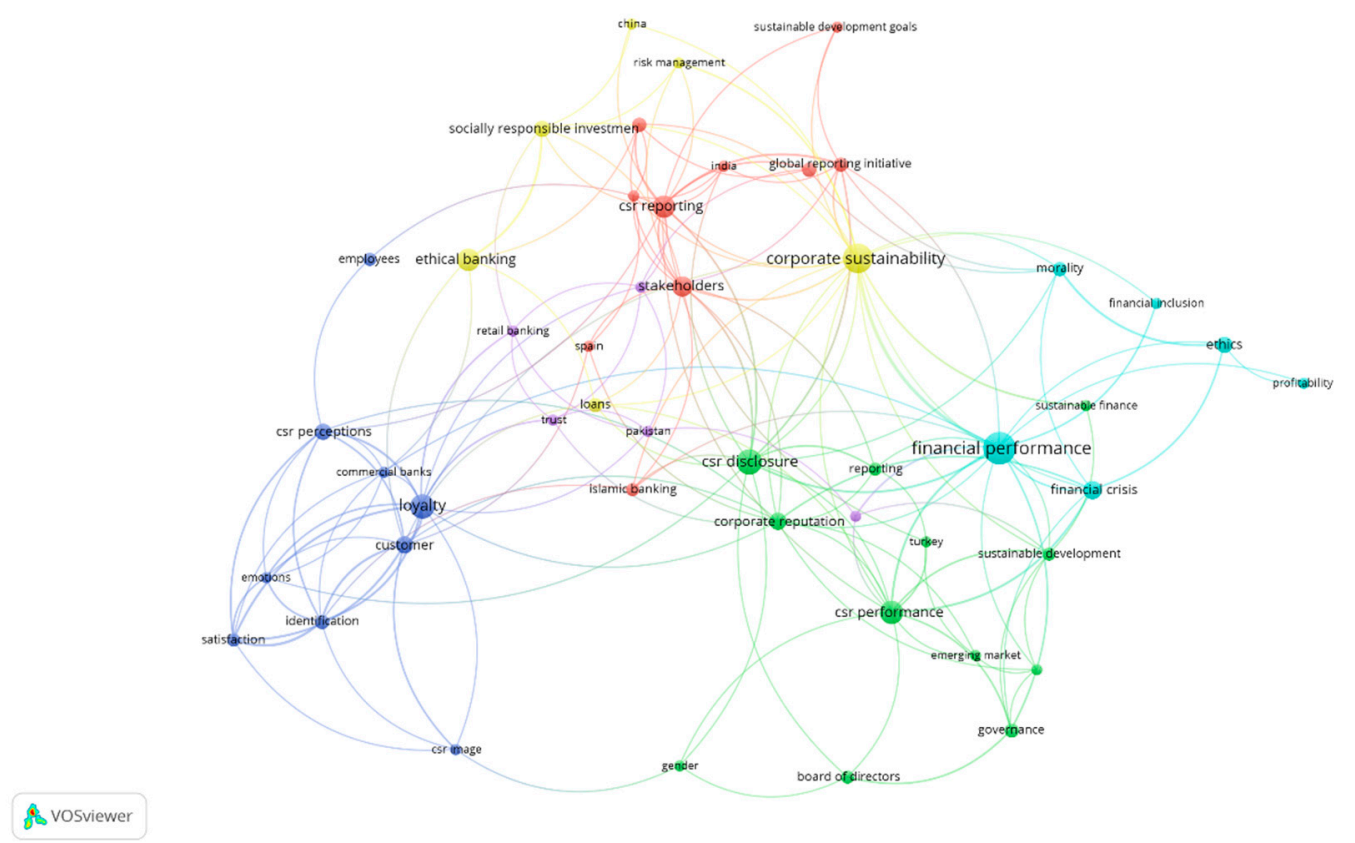

Figure 4. Thematic networks 2015-2019.

One can observe that the elements that form the different groups that coexist in the networks of each period, not only maintained relationships between one another, but also with elements of the rest of the groups. In general, clustering algorithms like the one used here involve grouping the terms according to the degree of co-occurrence, maximizing co-occurrence within the group. Logic says that terms that appear together in one or more documents are related.

To further represent the characteristics of the groups, some authors have used strategic diagrams based on centrality and density measures [24,32]. A strategic diagram identifies four types of themes, according to Callon et al. [32] "motor themes" appear in the upper right quadrant. Their characteristics include a high degree of internal development and strong ties to other concepts in a given research field. "Highly developed and isolated themes" are in the upper left quadrant. While they have a high degree of internal development their importance to the rest of the scientific area is marginal. "Emerging or declining themes" appear in the lower left quadrant. Emerging themes do not yet have sufficient relevance to the field studied, and may not gain this relevance. Declining themes have a high degree of internal development for the period studied, but have started to lose importance. Finally, "basic and transversal themes" are in the lower right quadrant. These themes show strong ties with issues outside the network, and are therefore relevant to the knowledge area considered. However, they have lower levels of internal development. The diagram is enriched based on the size of a circle that represents the topic, incorporating quantitative or qualitative measures in the graph following the proposal of Cobo et al. [15]. Examples of these metrics include number of documents in a network, number of references to documents in a network, and number of authors who have investigated a particular topic.

Each thematic group has been tagged with the word that has the highest level of centrality within each subnetwork. Figures 5 and 6 present strategic diagrams for the selected periods of time. In both cases, the size of the circles represents the number of main documents in which terms from each thematic group appear. Figures 7 and 8 represent networks of networks, that is, how thematic groups are interconnected. In these graphs, the thickness of the lines connecting the terms represents the intensity of the relationship between the two thematic networks. To calculate the centrality and density of each subnetwork, the weighted centrality of each node in Figures 7 and 8 (centrality) and the average degree of each subnetwork (density) has been computed. 


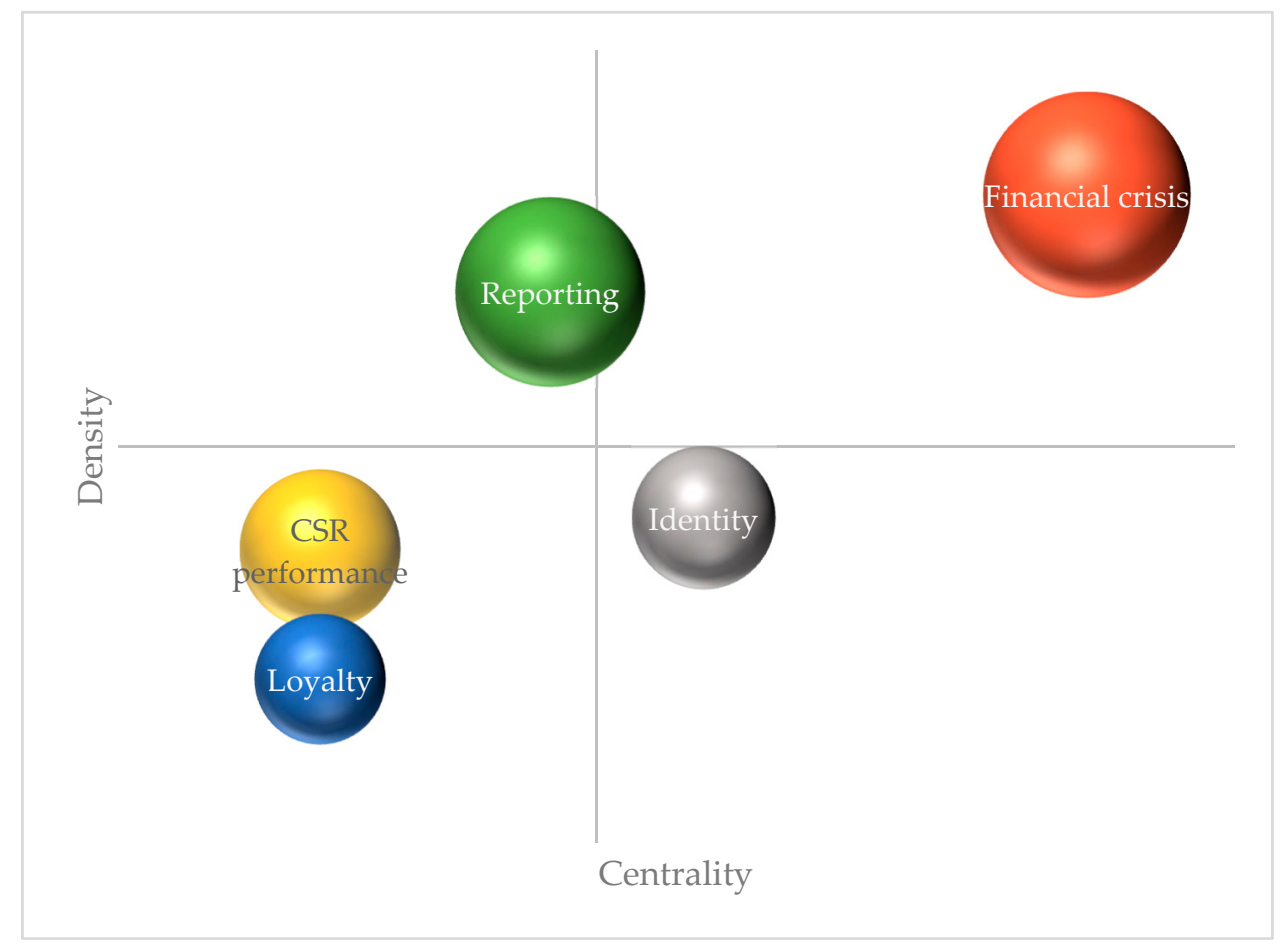

Figure 5. Strategic diagram for 2009-2014.

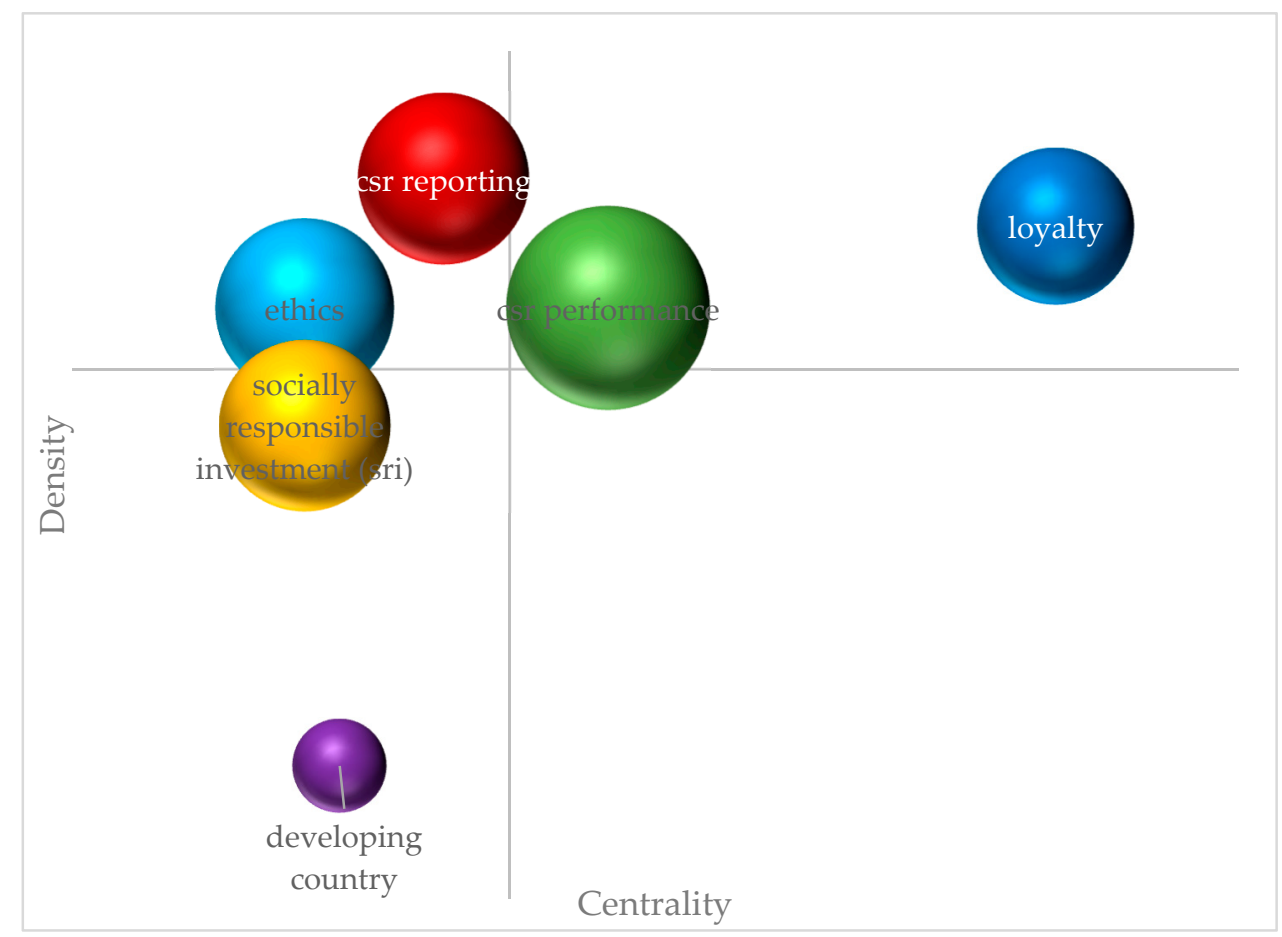

Figure 6. Strategic diagram for 2015-2019. 


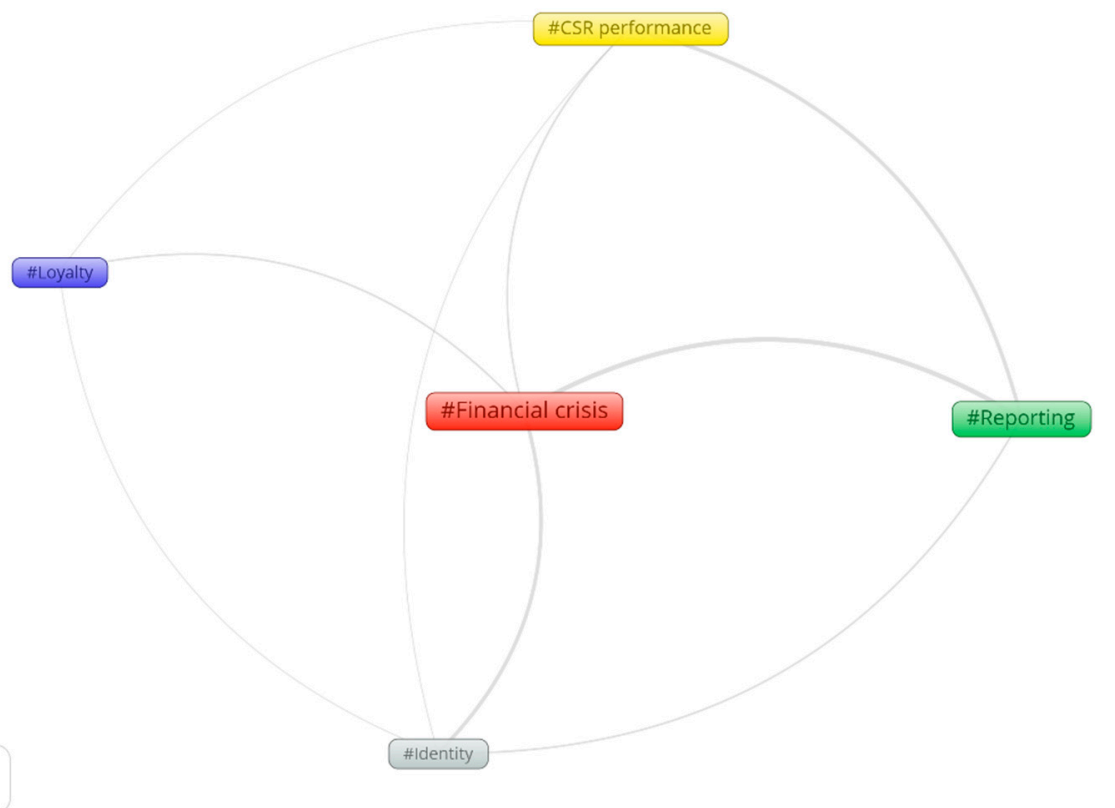

Figure 7. Relations between thematic networks (2009-2014).

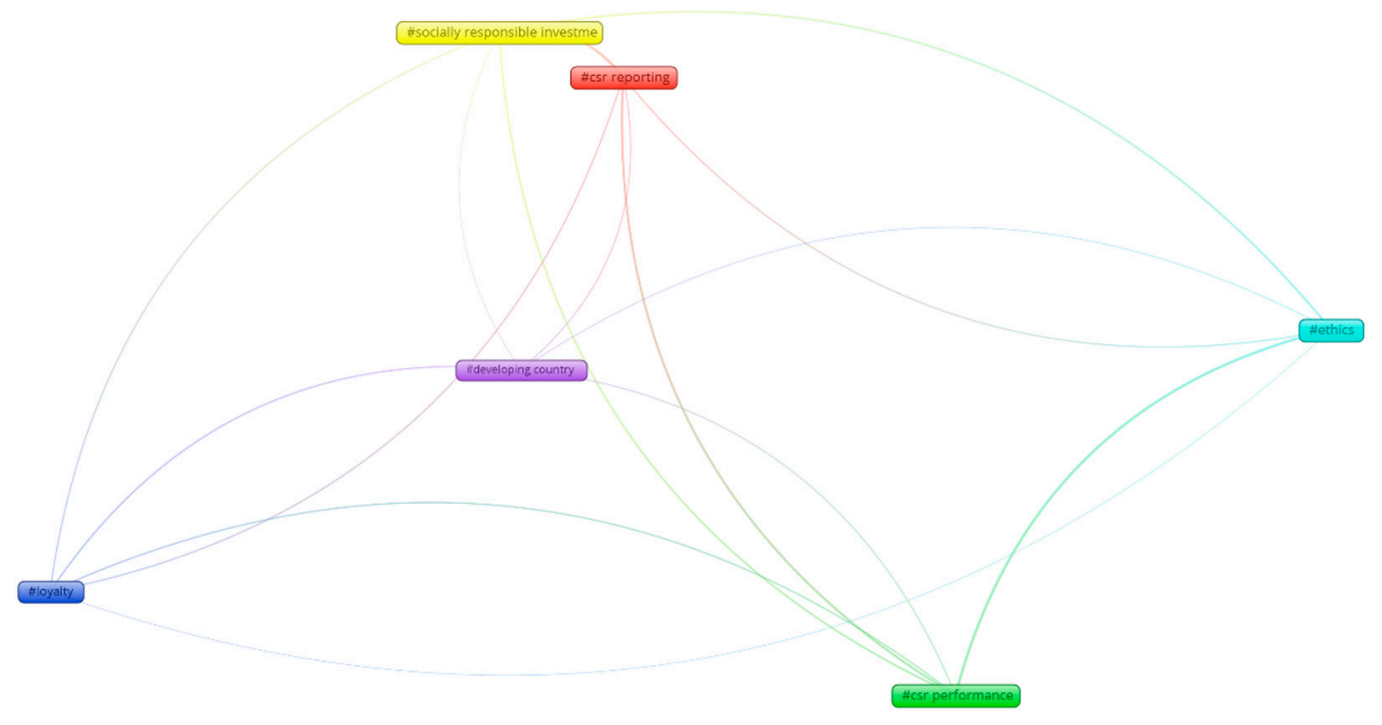

离 Vosviewer

Figure 8. Relations between thematic networks (2015-2019).

In the period 2009-2014, one can distinguish five thematic networks. The strategic matrix (Figure 5) clearly shows "financial crisis" as a motor theme, and the network with the highest number of documents (24). Figures 3 and 5 further demonstrate its critical role, as "financial crisis" appears in the center of these networks. One can observe stronger relationships between "financial crisis" and the themes of "reporting" and "identity", even though its central position connects it to the rest of the themes. In addition to its central component ("Financial crisis") this network, as can be seen in Figure 3, contains themes related to "ethical banking", "ethics", "leadership", "stakeholders" and "loans". These types of themes are part of the literature focused on explaining the reasons behind the 2008 financial crisis and which, in large measure, attribute it to a lack of ethics. Themes like "socially responsible investment (SRI)" and "Dow Jones sustainability index" are also connected to the central theme of "financial crisis", although more indirectly. These are the themes that establish a stronger relationship with the "reporting" network. 
In the quadrant of emerging/declining themes for this first period, one finds two thematic networks: "loyalty" and "CSR performance". "Loyalty" is the least developed of the themes in this period, with only nine documents and weak relationships with the rest of the themes. However, as one can notice in the complete network (Figure 3), the relationships between its elements are strong and coherent. Terms like "commitment", "satisfaction", "financial services" and "corporate reputation" make up a group with a significant focus on the study of the client. Thus, the strongest links of this network are the ones it has with "identity" and "CSR performance".

"CSR performance" contains themes addressed in 14 documents. As one can gather from Figure 3, within this theme are grouped a number of questions related to performance (not only "social", but also "financial performance"), "CSR reporting" and "CSR disclosure". This last term is particularly linked to obtaining advantages derived from exterior communication of actions carried out in the field of corporate social responsibility. The connection between "CSR performance" and "reporting" is the strongest among its connections to the other thematic networks.

The "reporting" network occupies a position in the strategic matrix between the quadrant for "Highly developed and isolated themes" and that of "Motor themes". One can observe as much in Figure 3 as in Figure 7 that the strongest relationships of this network are with the elements "financial crisis", "reporting" and "identity". The internal composition of this network mixes diverse themes like those highlighting "governance" and "corporate governance" together with "reporting". This clearly relates this topic to the analysis of corporate governance as a cause of the aforementioned financial crisis, and to the call for banks to implement measures to establish better controls.

Finally, the "identity" network aggregates themes linked to communication: "public relations" and "corporate image". Its location close to the "loyalty" network clearly demonstrates a line of investigation centered in communication and linked to the necessity to rebuild the client trust lost as a result of the financial crisis. In various works of this period, one observes how banks used CSR as a tool to carry out this task.

With respect to the period 2015-2019 (Figures 4, 6 and 8), six different thematic networks have been identified. One notes in the strategic matrix (Figure 6) that there are two motor themes: "Loyalty" and "CSR Performance". Twenty-eight documents in this period deal with "Loyalty". Its internal composition, in line with the group of the same name from the prior period, integrates different terms related to the client: "customer", "identification" and "emotions". It also includes aspects linked to the use of CSR as a competitive weapon: "CSR image" and "CSR perceptions" are clear examples. The connections of this group are stronger in this period, as can be seen as much in Figure 4 as in Figure 8. The most directly related groups are "CSR performance" (by way of "corporate reputation") and "developing country".

"CSR performance" is the other motor theme in this period. It has the highest number of documents dealing with it (48 documents). Internally, terms linked to corporate governance ("governance", "board of directors", "reporting" and "CSR disclosure") stand out, as well as its relationship with "corporate reputation". This links the theme to more competitive aspects. This double identity explains the relationships with "Loyalty" on the one hand, and with "Ethics" and "CSR reporting" on the other.

"CSR reporting" is a large group, made up of 10 different terms. Thirty-four documents in the period 2015-2019 deal with "CSR reporting". Terms linked to reporting ("Global Report Initiative" and "CSR reporting") and ethics ("legitimacy") appear in this group. However, its terms are also linked to aspects directly related to sustainable behavior ("sustainable development goals (SDGs)" and "social efficiency"). This makes it into a fairly general group that includes diverse themes trending in this moment. It occupies a relatively central position in the graphs, although its strongest relationships are with the subnetworks "CSR performance" and "socially responsible investment (SRI)".

The rest of the themes are located, more or less clearly, in the "emerging or declining themes" quadrant. The first of these themes, "Ethics" (37 documents), has a double nature: on one hand, aspects linked to ethics ("morality" and "financial inclusion") and on the other hand, terms linked to results ("financial performance" and "profitability"), inheriting the principal theme of the prior period 
("financial crisis"), which creates a catalyst for these two groups. Its connections are fewer than in prior cases, but even so, the connections with "CSR reporting" and "CSR performance" are strong.

Thirty-four documents deal with the theme of "socially responsible investment (SRI)" and the number of terms that make up this subnetwork is less, only six. It is a diverse group, with significant integration of the term "ethical banking", a topic closely related to "socially responsible investment (SRI)". Its connection groups are "Ethics" and "CSR reporting".

Finally, "developing country" is a small group, probably an emerging one, which includes terms addressed in a total of 10 documents. Its connections are strongest with "CSR performance" and "loyalty".

\subsection{Third Phase}

The purpose of this stage is to observe the evolution of themes. To analyze the full set of themes, the so-called stability index was used to measure overlap between two periods, i.e., the continuity or discontinuity between terms. Figure 9 illustrates the stability of the area of research and shows that the field was still nascent with a low rate of similarity and with a relatively high increase in different keywords. For the first period considered, there were 205 different keywords of which 91 remained in the following period and 114 left. In contrast, along with the 91 that remain, 288 new words were incorporated. This increase was explained in part by the growth in the number of articles published, as is shown in Figure 1, and partly by the change in themes, which is characteristic of a dynamic area of knowledge.

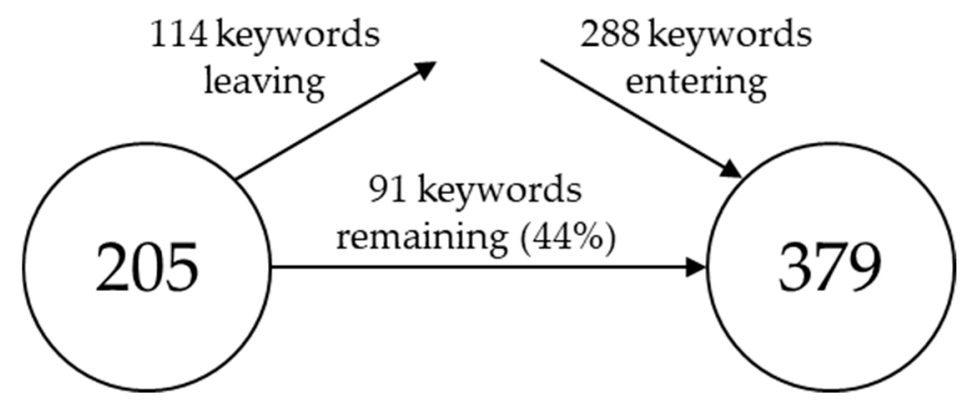

Figure 9. Overlap fractions.

Another interesting aspect is the relationship among themes in different periods. All the relationships among thematic groups in different periods are summed up in Figure 10, in which the thickness of the lines represents the intensity of the relationship.

"Financial crisis", a motor theme in the first period, has evolved in 2015-2019 to become two different thematic subnetworks: "socially responsible investment (SRI)", becoming a declining/emerging theme, and "Ethics", a highly developed and isolated theme. It is obvious that, with the passage of time, crisis became a less interesting theme, but CSR is now (in this last period), a competitive necessity in the financial industry.

"Reporting" had evolved toward different topics, although its most intense relationship was with the theme "CSR performance". In fact, "CSR performance" in the first period, was disseminated into four different themes in 2015-2019. "Loyalty" was the most continuous theme, as much in the terms included as in the focus of the theme. "Identity" did not continue in 2015-2019. 


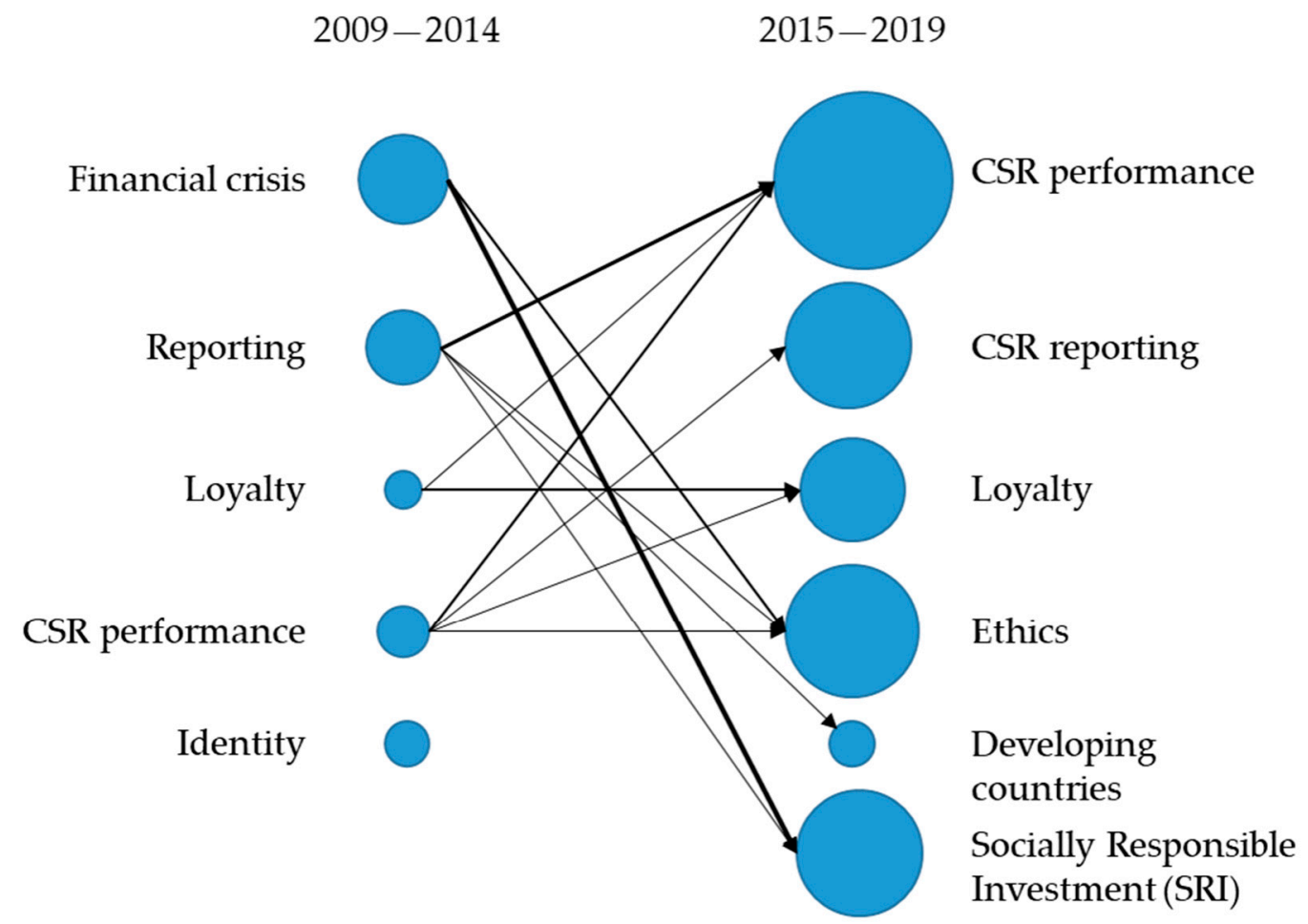

Figure 10. Thematic evolution of sustainable banking topic.

\subsection{Fourth Phase}

At this stage, a performance analysis was conducted. Cobo et al. [15] consider quantitative and qualitative measures of performance. Tables 11 and 12 show the performance metrics of the two periods analyzed.

Table 11. Performance metrics for 2009-2014.

\begin{tabular}{ccccc}
\hline Cluster & Documents & h-Index & Citations & Average of Citations \\
\hline Reporting & 21 & 11 & 514 & 25.7 \\
Financial crisis & 25 & 16 & 1023 & 42.6 \\
Identity & 12 & 8 & 551 & 50.1 \\
CSR performance & 15 & 11 & 561 & 11.0 \\
Loyalty & 10 & 5 & 251 & 27.9 \\
\hline
\end{tabular}

Table 12. Performance metrics for 2015-2019.

\begin{tabular}{ccccc}
\hline Cluster & Documents & h-Index & Citations & Average of Citations \\
\hline CSR performance & 48 & 11 & 69 & 2.9 \\
CSR reporting & 34 & 8 & 90 & 3.8 \\
Loyalty & 28 & 8 & 160 & 6.7 \\
Ethics & 37 & 9 & 71 & 9.0 \\
Socially Responsible & 34 & 10 & 116 & 4.8 \\
Investment (SRI) & 10 & 4 & 68 & 6.2 \\
Developing country & & & & \\
\hline
\end{tabular}

The results of this phase show that in the period 2009-2014, the "Financial crisis" sub-network has better metrics except for the average amount of citations. In that metric, "Identity" was the best theme. In the 2015-2019 period, the results are more homogeneous, except for the "Developing country" network, which has a significantly lower amount of documents than the rest. 


\section{Discussion}

This paper reviewed existing literature on sustainable banking for three periods: prior to and including 2008, 2009-2014 and 2015-2019. First, a descriptive bibliometric analysis was carried out. Second, subtopics analyzed in the literature and their relationships (conceptual structure) were identified through a co-word analysis, one of the less commonly used bibliometric techniques (13.6\%) in business studies [11]. This study, as far as I know, is the only one to approach this topic from this perspective.

Some interesting conclusions were revealed by the descriptive statistical analysis. First, literature on this subject began to develop after the 2008 financial crisis. The banking sector has long been excluded from the discussion in the field of CSR [13,36]. However, the effect of one of the deepest economic crises in history, encouraged banks to look at CSR as a way to recover their reputation (image) [14]. In addition, the acceleration of the topic in the last two years is noticeable, with close to 50 documents (articles and reviews) in the WoS database in 2019. This growth clearly expresses the interest of academics, which usually reflects practitioner behavior.

First, with regard to authors, one must highlight the existence of a relatively closed but extraordinarily productive group in the University of Cantabria. Professors Pérez and Rodríguez del Bosque stand out as having worked in fields strongly linked to marketing.

Regarding collaboration, the multidisciplinary nature of the subject and the specificity of banking have resulted in high social science collaboration for a topic that is still relatively young, as is confirmed by the analysis of Lotka's Law. Furthermore, one notices the limitation suggested by the scientific activity, with a very small percentage of research works having more than four authors.

The concentration of studies of this theme in Europe is noteworthy, while at the same time, interest in the United States is low. One must also point out the growth of studies in Asian universities.

The Journal of Business Ethics is the journal of reference for this topic, having published close to $20 \%$ of the documents considered in the database for this study. Sustainability made a strong showing in the subject, with more than $8 \%$ of documents, keeping in mind the journal's newness in WoS. One must also highlight, as other publications essential to the topic, the roles played by corporate social responsibility and environmental management. It is, however, interesting to note the small echo this subject has generated in journals more specialized in the sector, with the exception of the International Journal of Bank Marketing. Even so, the number of documents published by this journal related to this topic is relatively small.

With respect to the analysis of themes, in the period 2009-2014, the main theme around which the rest revolved was the financial crisis [37-47]. It is true that on many occasions this theme is the catalyst to address other questions that fundamentally fall into three branches: the role of banks as instigators of the crisis, the study of how to implement policies of CSR, and the consequences for specific agents implicated in said implementation. In the first of these branches, there are diverse studies related to ethics [37-39,42] and the necessity of introducing changes to the corporate governance of banks [47]. In the second, dealing with how to implement policies, various works confront themes linked with CSR disclosure and reporting [44,48,49], as a way to measure the policies [1] and influence the formation of a corporate identity $[50,51]$. Finally, in the third branch, studies about the connection between CSR performance and financial performance $[52,53]$ and about the effects of CSR on the client $[8,54-57]$ are highlighted.

Evolution in the period 2015-2019 has changed the investigative panorama in sustainable banking, although several themes from the first period remain. First, studies about loyalty have moved to occupy a highlighted position as a research driver in this terrain, with a high volume of scientific production [9,14,58-75]. Together with clients, employees have been added as another relevant stakeholder, and one for whom sustainable banking also has effects [76-79]. In the line of CSR performance, which is more central in this second period, one finds a large quantity of studies that border the relationship between surrender of corporate social responsibility and financial performance [6,80-92]. One explanation of such significant growth in the works in this area is that 
it is due to the availability of new sources of data that consider measurements of CSR performance. In much smaller measure, but also of interest, some studies border a middle area, which is the relationship between CSR performance and corporate reputation $[10,13]$. In the field of studies that are more about banks' behavior in CSR, noteworthy studies include some that have addressed financial inclusion [6,87,93], about CSR reporting and Global Reporting Initiative [94-98], not forgetting studies that continue the line of Socially Responsible Investment [99,100]. Finally, it is also interesting to note how in this last period, various studies that consider the theme in developing countries have emerged [58,101-106].

Evolution, the availability of data and the sector's relevance, and the greater incorporation of this type of strategy on the part of banks could suggest that in coming years, themes around sustainable banking will continue to grow. That evolution, in my opinion and viewing the data that this analysis has facilitated, will highlight two aspects. First, greater variety in themes, including in the analysis different stakeholders who, up to today, have been studied in a more marginal way. So, employees, public organizations and shareholders will occupy bigger spaces in this research. Furthermore, research models will incorporate new variables into questions central to the subject. For example, around the relationship between CSR performance and the different aspects that affect or are consequences of banks' competitiveness, new variables will be incorporated that model this relationship and offer more solid explanations. Finally, although the journals that have lead the publication of these studies will continue to do so, more journals specialized in the banking sector will be included.

As future research lines, in view of the results obtained and the configuration of the theme, the utilization of other bibliometric techniques could be valuable. In this sense, the proposals go in two lines: to study the intellectual foundation using an analysis of co-citation [107] and, especially, to study a bibliographic coupling [108] that allows the derivation of different latent research groups in the area.

Funding: This paper has been supported by Project RTI2018-097447-B-I00 of the Ministry of Science, Innovation and Universities (Spain).

Conflicts of Interest: The author declares no conflict of interest.

\section{References}

1. Scholtens, B. Corporate social responsibility in the international banking industry. J. Bus. Ethics 2009, 86, 159-175. [CrossRef]

2. Jeucken, M. Sustainable Finance and Banking: The Financial Sector and the Future of the Planet; Routledge: London, UK, 2010.

3. Shen, C.; Lee, C. Same financial development yet different economic growth-Why? J. Money Credit Bank. 2006, 38, 1907-1944. [CrossRef]

4. Beck, T.; Demirgüç-Kunt, A.; Levine, R. Financial institutions and markets across countries and over time: The updated financial development and structure database. Wber 2010, 24, 77-92. [CrossRef]

5. Yip, A.W.H.; Bocken, N.M.P. Sustainable business model archetypes for the banking industry. J. Clean. Prod. 2018, 174, 150-169. [CrossRef]

6. Nizam, E.; Ng, A.; Dewandaru, G.; Nagayev, R.; Nkoba, M.A. The Impact of social and environmental sustainability on financial performance: A global analysis of the banking sector. J. Multinatl. Financ. Manag. 2019, 49, 35-53. [CrossRef]

7. Arnason, V. Moral analysis of an economic collapse-An exercise in practical ethics. Etikk Praksis 2010, 4, 101-123. [CrossRef]

8. Ruiz, B.; Esteban, A.; Gutierrez, S. Determinants of reputation of leading spanish financial institutions among their customers in a context of economic crisis. BRQ Bus. Res. Q. 2014, 17, 259-278. [CrossRef]

9. Ruiz, B.; Garcia, J.A.; Revilla, A.J. Antecedents and consequences of bank reputation: A comparison of the United Kingdom and Spain. Int. Market. Rev. 2016, 33, 781-805. [CrossRef]

10. Dell'Atti, S.; Trotta, A.; Iannuzzi, A.P.; Demaria, F. Corporate social responsibility engagement as a determinant of bank reputation: An empirical analysis. Corp. Soc. Responsib. Environ. Manag. 2017, 24, 589-605. [CrossRef] 
11. Bouma, J.J.; Jeucken, M.; Klinkers, L. Sustainable Banking: The Greening of Finance; Routledge: London, UK, 2017.

12. Zupic, I.; Čater, T. Bibliometric methods in management and organization. Organ. Res. Methods 2015, 18, 429-472. [CrossRef]

13. Forcadell, F.J.; Aracil, E. European banks' reputation for corporate social responsibility. Corp. Soc. Responsib. Environ. Manag. 2017, 24, 1-14. [CrossRef]

14. Agirre Aramburu, I.; Gomez Pescador, I. The effects of corporate social responsibility on customer loyalty: The mediating effect of reputation in cooperative banks versus commercial banks in the basque country. J. Bus. Ethics 2019, 154, 701-719. [CrossRef]

15. Cobo, M.J.; López-Herrera, A.G.; Herrera-Viedma, E.; Herrera, F. An approach for detecting, quantifying, and visualizing the evolution of a research field: A practical application to the fuzzy sets theory field. J. Informetr. 2011, 5, 146-166. [CrossRef]

16. Muñoz-Leiva, F.; Viedma-del-Jesús, M.I.; Sánchez-Fernández, J.; López-Herrera, A.G. An application of co-word analysis and bibliometric maps for detecting the most highlighting themes in the consumer behaviour research from a longitudinal perspective. Qual. Quant. 2012, 46, 1077-1095. [CrossRef]

17. Lee, S.; Bozeman, B. The impact of research collaboration on scientific productivity. Soc. Stud. Sci. 2005, 35, 673-702. [CrossRef]

18. Katz, J.S.; Martin, B.R. What is research collaboration? Res. Policy 1997, 26, 1-18. [CrossRef]

19. Gazni, A.; Didegah, F. Investigating different types of research collaboration and citation impact: A case study of harvard university publications. Scientometrics 2011, 87, 251-265. [CrossRef]

20. Sooryamoorthy, R. Do types of collaboration change citation? Collaboration and citation patterns of south african science publications. Scientometrics 2009, 81, 177. [CrossRef]

21. Mora-Valentín, E.; Ortiz-de-Urbina-Criado, M.; Nájera-Sánchez, J. Mapping the Conceptual Structure of Science and Technology Parks. J. Technol. Transfer 2018, 43, 1410-1435. [CrossRef]

22. Lotka, A.J. The frequency distribution of scientific productivity. J. Wash. Acad. Sci. 1926, 16, 317-323.

23. de Solla Price, D.J.; Beaver, D. Collaboration in an invisible college. Am. Psychol. 1966, 21, 1011. [CrossRef] [PubMed]

24. He, Q. Knowledge discovery through co-word analysis. Libr. Trends 1999, 48, 133-159.

25. Garfield, E. Scientography: Mapping the tracks of science. Curr. Contents Soc. Behav. Sci. 1994, 7, 5-10.

26. Callon, M.; Courtial, J.; Turner, W.A.; Bauin, S. From translations to problematic networks: An introduction to co-word analysis. Information (Int. Soc. Sci. Counc.) 1983, 22, 191-235. [CrossRef]

27. Coulter, N.; Monarch, I.; Konda, S. Software engineering as seen through its research literature: A study in co-word analysis. J. Am. Soc. Inf. Sci. 1998, 49, 1206-1223. [CrossRef]

28. Choi, J.; Yi, S.; Lee, K.C. Analysis of keyword networks in MIS research and implications for predicting knowledge evolution. Inf. Manag. 2011, 48, 371-381. [CrossRef]

29. Van Eck, N.J.; Waltman, L. Software survey: VOSviewer, a computer program for bibliometric mapping. Scientometrics 2010, 84, 523-538. [CrossRef]

30. Persson, O.; Danell, R.; Schneider, J.W. How to use Bibexcel for Various Types of Bibliometric Analysis. Celebr. Sch. Commun. Stud. 2009, 5, 9-24.

31. De Nooy, W.; Mrvar, A.; Batagelj, V. Exploratory Social Network Analysis with Pajek; Cambridge University Press: Cambridge, UK, 2011.

32. Callon, M.; Courtial, J.P.; Laville, F. Co-word analysis as a tool for describing the network of interactions between basic and technological research: The case of polymer chemsitry. Scientometrics 1991, 22, 155-205. [CrossRef]

33. van Eck, N.J.; Waltman, L. How to normalize cooccurrence data? An analysis of some well-known similarity measures. J. Am. Soc. Inf. Sci. Technol. 2009, 60, 1635-1651. [CrossRef]

34. van Eck, N.J.; Waltman, L.; Dekker, R.; van den Berg, J. A comparison of two techniques for bibliometric mapping: Multidimensional scaling and VOS. J. Am. Soc. Inf. Sci. Technol. 2010, 61, 2405-2416. [CrossRef]

35. Waltman, L.; van Eck, N.J.; Noyons, E.C. A unified approach to mapping and clustering of bibliometric networks. J. Informetr. 2010, 4, 629-635. [CrossRef]

36. Wu, M.; Shen, C.; Chen, T. Application of multi-level matching between financial performance and corporate social responsibility in the banking industry. Rev. Quant. Finance Account. 2017, 49, 29-63. [CrossRef] 
37. Fassin, Y.; Gosselin, D. The collapse of a European bank in the financial crisis: An analysis from stakeholder and ethical perspectives. J. Bus. Ethics 2011, 102, 169-191. [CrossRef]

38. Graafland, J.J.; van de Ven, B.W. The Credit crisis and the moral responsibility of professionals in finance. J. Bus. Ethics 2011, 103, 605-619. [CrossRef]

39. Fonteyne, W.; Hardy, D.C. Cooperative banking and ethics: Past, present and future. Ethical Perspect. 2011, 18, 491-514. [CrossRef]

40. Perez-Ruiz, A.; Rodriguez-del Bosque, I. Corporate social responsibility image in a financial crisis context: The case of the Spanish financial industry. Univ. Bus. Rev. 2012, 33, 14-29.

41. Sigurthorsson, D. The Icelandic banking crisis: A reason to rethink CSR? J. Bus. Ethics 2012, 111, 147-156. [CrossRef]

42. Jin, K.G.; Drozdenko, R.; DeLoughy, S. The role of corporate value clusters in ethics, social responsibility, and performance: A study of financial professionals and implications for the financial meltdown. J. Bus. Ethics 2013, 112, 15-24. [CrossRef]

43. Herzig, C.; Moon, J. Discourses on corporate social ir/responsibility in the financial sector. J. Bus. Res. 2013, 66, 1870-1880. [CrossRef]

44. Jizi, M.I.; Salama, A.; Dixon, R.; Stratling, R. Corporate governance and corporate social responsibility disclosure: Evidence from the US banking sector. J. Bus. Ethics 2014, 125, 601-615. [CrossRef]

45. Laidroo, L.; Oeoebik, U. Banks' CSR disclosures-Headquarters versus subsidiaries. Balt. J. Manag. 2014, 9 , 47-70. [CrossRef]

46. McCann, J.; Sweet, M. The perceptions of ethical and sustainable leadership. J. Bus. Ethics 2014, 121, $373-383$. [CrossRef]

47. Jonsson, S. The appropriate banker and the need for ontological re-positioning. Scand. J. Manag. 2014, 30, 372-381. [CrossRef]

48. Sobhani, F.A.; Zainuddin, Y.; Amran, A.; Baten, M.A. Corporate sustainability disclosure practices of selected banks: A trend analysis approach. Afr. J. Bus. Manag. 2011, 5, 2794-2804.

49. Carnevale, C.; Mazzuca, M.; Venturini, S. Corporate social reporting in European banks: The effects on a firm's market value. Corp. Soc. Responsib. Environ. Manag. 2012, 19, 159-177. [CrossRef]

50. Bravo, R.; Matute, J.; Pina, J.M. Corporate social responsibility as a vehicle to reveal the corporate identity: A study focused on the websites of Spanish financial entities. J. Bus. Ethics 2012, 107, 129-146. [CrossRef]

51. Perez, A.; Rodriguez del Bosque, I. The role of CSR in the corporate identity of banking service providers. J. Bus. Ethics 2012, 108, 145-166. [CrossRef]

52. Cabeza-Garcia, L.; Martinez-Campillo, A.; Marbella-Sanchez, F. Corporate social responsibility and business performance: The case of social work at Spanish savings banks. INNOVAR Rev. Cienc. Adm. Soc. 2010, 20, 33-46.

53. Soana, M. The relationship between corporate social performance and corporate financial performance in the banking sector. J. Bus. Ethics 2011, 104, 133-148. [CrossRef]

54. Matute-Vallejo, J.; Bravo, R.; Pina, J.M. The influence of corporate social responsibility and price fairness on customer behaviour: Evidence from the financial sector. Corp. Soc. Responsib. Environ. Manag. 2011, 18, 317-331. [CrossRef]

55. Chomvilailuk, R.; Butcher, K. Effects of quality and corporate social responsibility on loyalty. Serv. Ind. J. 2014, 34, 938-954. [CrossRef]

56. Finazzi Santos, P.M.; Porto, R.B. Environmental responsability and customers loyalty in retail bank. RAE-Rev. Adm. Empres. 2014, 54, 606-618. [CrossRef]

57. Vilanova, M.; Lozano, J.M.; Arenas, D. Exploring the nature of the relationship between CSR and competitiveness. J. Bus. Ethics 2009, 87, 57-69. [CrossRef]

58. Khan, Z.; Ferguson, D.; Perez, A. Customer responses to CSR in the Pakistani banking industry. Int. J. Bank Mark. 2015, 33, 471-493. [CrossRef]

59. Perez, A.; Rodriguez del Bosque, I. How customer support for corporate social responsibility influences the image of companies: Evidence from the banking industry. Corp. Soc. Responsib. Environ. Manag. 2015, 22, 155-168. [CrossRef]

60. Perez, A.; Rodriguez del Bosque, I. How customers construct corporate social responsibility images: testing The moderating role of demographic characteristics. BRQ Bus. Res. Q. 2015, 18, 127-141. [CrossRef] 
61. Perez, A.; Rodriguez del Bosque, I. Customer responses to the CSR of banking companies. J. Prod. Brand Manag. 2015, 24, 481-493. [CrossRef]

62. Perez, A.; Rodriguez del Bosque, I. Corporate social responsibility and customer loyalty: Exploring the role of identification, satisfaction and type of company. J. Serv. Mark. 2015, 29, 15-25. [CrossRef]

63. Perez, A.; Rodriguez del Bosque, I. An integrative framework to understand how CSR affects customer loyalty through identification, emotions and satisfaction. J. Bus. Ethics 2015, 129, 571-584. [CrossRef]

64. Fatma, M.; Khan, I.; Rahman, Z. How does corporate association influence consumer brand loyalty? Mediating role of brand identification. J. Prod. Brand Manag. 2016, 25, 629-641. [CrossRef]

65. Mostafa, R.B.; ElSahn, F. Exploring the mechanism of consumer responses to CSR activities of Islamic banks the mediating role of Islamic ethics fit. Int. J. Bank Mark. 2016, 34, 940-962. [CrossRef]

66. Perez, A.; Rodriguez del Bosque, I. The stakeholder management theory of CSR a multidimensional approach in understanding customer identification and satisfaction. Int. J. Bank Mark. 2016, 34, 731-751. [CrossRef]

67. Callejas-Albinana, F.E.; Martinez-Rodriguez, I.; Callejas-Albinana, A.I.; de Vidales-Carrasco, I.M. Assessing the growth of ethical banking: Some evidence from Spanish customers. Front. Psychol. 2017, 8, 782. [CrossRef]

68. Moisescu, O.; Gica, O. The moderating influence of consumer demographics on the relationship between perceived CSR and brand loyalty in the Romanian retail banking sector. EM Ekon. Manag. 2017, 20, 187-202. [CrossRef]

69. Perez, A.; del Bosque, I.R. Personal traits and customer responses to CSR perceptions in the banking sector. Int. J. Bank Mark. 2017, 35, 128-146. [CrossRef]

70. Saeidi, I.P.; Othman, M.S.H.; Streimikiene, D.; Saaeidi, S.A.; Saeidi, P.; Mardani, A. Identifying the gap and differences between customers' expectations for banks' corporate social responsibility and the actual scenario. Transform. Bus. Econ. 2017, 16, 106-123.

71. del Mar García-De los Salmones, M.; Perez, A. Effectiveness of CSR advertising: The role of reputation, consumer attributions, and emotions. Corp. Soc. Responsib. Environ. Manag. 2018, 25, 194-208. [CrossRef]

72. Abbas, M.; Gao, Y.; Shah, S.S.H. CSR and customer outcomes: The mediating role of customer engagement. Sustainability 2018, 10, 4243. [CrossRef]

73. Igbudu, N.; Garanti, Z.; Popoola, T. Enhancing bank loyalty through sustainable banking practices: The mediating effect of corporate image. Sustainability 2018, 10, 4050. [CrossRef]

74. Ajina, A.S.; Japutra, A.; Nguyen, B.; Alwi, S.F.S.; Al-Hajla, A.H. The importance of CSR initiatives in building customer support and loyalty: Evidence from Saudi Arabia. Asia Pac. J. Market. Logist. 2019, 31, 691-713. [CrossRef]

75. Ibe-enwo, G.; Igbudu, N.; Garanti, Z.; Popoola, T. Assessing the relevance of green banking practice on bank loyalty: The mediating effect of green image and bank trust. Sustainability 2019, 11, 4651. [CrossRef]

76. Brandao, I.d.F.; Miranda Diogenes, A.S.; Sa de Abreu, M.C. Value allocation to stakeholder employees and its effect on the competitiveness of the banking sector. RBGN Rev. Bras. Gest. Negoc. 2017, 19, 161-179. [CrossRef]

77. Bravo, R.; Buil, I.; de Chernatony, L.; Martinez, E. Brand identity management and corporate social responsibility: An analysis from employees' perspective in the banking sector. J. Bus. Econ. Manag. 2017, 18, 241-257. [CrossRef]

78. Rosati, F.; Costa, R.; Calabrese, A.; Pedersen, E.R.G. Employee attitudes towards corporate social responsibility: A study on gender, age and educational level differences. Corp. Soc. Responsib. Environ. Manag. 2018, 25, 1306-1319. [CrossRef]

79. Farid, T.; Iqbal, S.; Ma, J.; Castro-Gonzalez, S.; Khattak, A.; Khan, M.K. Employees' perceptions of CSR, work engagement, and organizational citizenship behavior: The mediating effects of organizational justice. Int. J. Environ. Res. Public Health 2019, 16, 1731. [CrossRef] [PubMed]

80. Cornett, M.M.; Erhemjamts, O.; Tehranian, H. Greed or good deeds: An examination of the relation between corporate social responsibility and the financial performance of US commercial banks around the financial crisis. J. Bank Financ. 2016, 70, 137-159. [CrossRef]

81. Esteban-Sanchez, P.; de la Cuesta-Gonzalez, M.; Diego Paredes-Gazquez, J. Corporate social performance and its relation with corporate financial performance: International evidence in the banking industry. J. Clean. Prod. 2017, 162, 1102-1110. [CrossRef] 
82. Halamka, R.; Teply, P. The effect of ethics on banks' financial performance. Prague Econ. Pap. 2017, 26, 330-344. [CrossRef]

83. Raut, R.; Cheikhrouhou, N.; Kharat, M. Sustainability in the banking industry: A strategic multi-criterion analysis. Bus. Strateg. Environ. 2017, 26, 550-568. [CrossRef]

84. Fijalkowska, J.; Zyznarska-Dworczak, B.; Garsztka, P. Corporate social-environmental performance versus financial performance of banks in Central and Eastern European countries. Sustainability 2018, 10, 772. [CrossRef]

85. Laguir, I.; Marais, M.; El Baz, J.; Stekelorum, R. Reversing the business rationale for environmental commitment in banking: Does financial performance lead to higher environmental performance? Manag. Decis. 2018, 56, 358-375. [CrossRef]

86. Platonova, E.; Asutay, M.; Dixon, R.; Mohammad, S. The impact of corporate social responsibility disclosure on financial performance: Evidence from the GCC Islamic banking sector. J. Bus. Ethics 2018, 151, 451-471. [CrossRef]

87. Bhattacharyya, A.; Wright, S.; Rahman, M.L. Is better banking performance associated with financial inclusion and mandated CSR expenditure in a developing country? Account. Financ. 2019. [CrossRef]

88. Brogi, M.; Lagasio, V. Environmental, social, and governance and company profitability: Are financial intermediaries different? Corp. Soc. Responsib. Environ. Manag. 2019, 26, 576-587. [CrossRef]

89. Gangi, F.; Mustilli, M.; Varrone, N. The impact of corporate social responsibility (CSR) knowledge on corporate financial performance: Evidence from the European banking industry. J. Knowl. Manag. 2019, 23, 110-134. [CrossRef]

90. Marin-Hernandez, S.; Ortiz-Martinez, E. Banking industry: Profitability and social responsibility. Asia Pac. J. Account. Econ. 2019. [CrossRef]

91. Matuszak, L.; Rozanska, E. A non-linear and disaggregated approach to studying the impact of CSR on accounting profitability: Evidence from the Polish banking industry. Sustainability 2019, 11, 183. [CrossRef]

92. Mar Miralles-Quiros, M.; Luis Miralles-Quiros, J.; Redondo Hernandez, J. ESG Performance and shareholder value creation in the banking industry: International differences. Sustainability 2019, 11, 1404. [CrossRef]

93. Gambetta, N.; Antonia Garcia-Benau, M.; Zorio-Grima, A. Corporate social responsibility and bank risk profile: evidence from Europe. Serv. Bus. 2017, 11, 517-542. [CrossRef]

94. Lock, I.; Seele, P. Analyzing sector-specific CSR reporting: Social and environmental disclosure to investors in the chemicals and banking and insurance industry. Corp. Soc. Responsib. Environ. Manag. 2015, 22, 113-128. [CrossRef]

95. Islam, M.A.; Jain, A.; Thomson, D. Does the global reporting initiative influence sustainability disclosures in asia-pacific banks? Australas. J. Environ. Manag. 2016, 23, 298-313. [CrossRef]

96. Kumar, R.; Pande, N.; Afreen, S. Developing a GRI-G4-based persuasive communication framework for sustainability reporting (SR) examining top 10 Indian banks. Int. J. Emerg. Mark. 2018, 13, 136-161. [CrossRef]

97. Masud, M.A.K.; Hossain, M.S.; Kim, J.D. Is green regulation effective or a failure: Comparative Analysis between Bangladesh bank (BB) green guidelines and global reporting initiative guidelines. Sustainability 2018, 10, 1267. [CrossRef]

98. Bonifacio Neto, J.; Branco, M.C. Controversial sectors in banks' sustainability reporting. Int. J. Sustain. Dev. World Ecol. 2019, 26, 495-505. [CrossRef]

99. Krause, K.; Battenfeld, D. Coming out of the Niche? Social banking in Germany: An empirical analysis of consumer characteristics and market size. J. Bus. Ethics 2019, 155, 889-911. [CrossRef]

100. Manuela Palacios-Gonzalez, M.; Chamorro-Mera, A. Analysis of the intention to invest in a socially responsible manner: A segmentation of the Spanish investor. Span. J. Financ. Account. 2019. [CrossRef]

101. Sun, J.; Wang, F.; Wang, F.; Yin, H. Community institutions and initial diffusion of corporate social responsibility practices in China's banking industry. Manag. Organ. Rev. 2015, 11, 441-468. [CrossRef]

102. Forcadell, F.J.; Aracil, E. Sustainable banking in Latin American developing countries: Leading to (mutual) prosperity. Bus. Ethics 2017, 26, 382-395. [CrossRef]

103. Weber, O. Corporate sustainability and financial performance of Chinese banks. Sustain. Account. Manag. Policy J. 2017, 8, 358-385. [CrossRef]

104. Iqbal, S.; Farid, T.; Ma, J.; Khattak, A.; Nurunnabi, M. The impact of authentic leadership on organizational citizenship behaviours and the mediating role of corporate social responsibility in the banking sector of Pakistan. Sustainability 2018, 10, 2170. [CrossRef] 
105. Sarfraz, M.; Qun, W.; Hui, L.; Abdullah, M.I. Environmental risk management strategies and the moderating role of corporate social responsibility in project financing decisions. Sustainability 2018, 10, 2771. [CrossRef]

106. Forcadell, F.J.; Aracil, E. Can multinational companies foster institutional change and sustainable development in emerging countries? A case study. Bus. Strategy Dev. 2019, 2, 91-105. [CrossRef]

107. Small, H. Co-citation in the scientific literature: A new measure of the relationship between two documents. J. Am. Soc. Inf. Sci. 1973, 24, 265-269. [CrossRef]

108. Kessler, M.M. Bibliographic coupling between scientific papers. Am. Doc. 1963, 14, 10-25. [CrossRef]

(C) 2019 by the author. Licensee MDPI, Basel, Switzerland. This article is an open access article distributed under the terms and conditions of the Creative Commons Attribution (CC BY) license (http://creativecommons.org/licenses/by/4.0/). 